\title{
PKM PERLINDUNGAN ANAK PADA MASYARAKAT KELURAHAN KINILOW I TOMOHON
}

\author{
Ruth Sriana Umbase \\ Program Studi Pendidikan Sejarah, Fakultas Ilmu Sosial, \\ Universitas Negeri Manado (UNIMA) \\ ruthumbase@unima.ac.id
}

\begin{abstract}
Abstrak
Secara umum terdapat empat jenis kekerasan pada anak yaitu kekerasan fisik, kekerasan verbal, kekerasan emosional dan kekerasan seksual. Setiap kekerasan menimbulkan penderitaan secara fisik, mental, seksual, psikologis pada anak. Hasil penelitian menunjukkan bahwa pelaku tindak kekerasan pada anak (80\%) adalah orang yang dekat dengan anak, seperti orang tua, saudara, tetangga, pengasuh, guru, dan lainlain. Pada tahun 2016 Kelurahan Kinilow I telah dipilih untuk pelaksanaan Gerakan Perlindungan Anak Terpadu Berbasis Masyarakat (PATBM). Di kelurahan tersebut berdasarkan laporan masyarakat ternyata sering terjadi tindak kekerasan. Masih banyak orang tua yang menganggap bahwa perlakuan salah dengan memukul, menampar, membenturkan kepala anak, mencubit, meremehkan, mengancam anak merupakan hal yang benar guna mendidik dan mendisiplin anak. Demikian juga penelantaran anak dan eksploitasi terhadap anak dianggap urusan dari orang tua. Oleh sebab itu maka perlu dibentuk gugus perlindungan anak dengan cara melakukan pelatihan PATBM terhadap perangkat desa, tokoh masyarakat, tokoh agama, dan anggota masyarakat. Hasil pelaksanaan kegiatan menunjukkan adanya peningkatan pengetahuan, keterampilan dan kesadaran peserta pelatihan dalam pemenuhan hak dan perlindungan anak. Hasil ini tentu saja perlu terus ditindak-lanjuti sehingga menjadi suatu kebiasaan yang positif bagi masyarakat. Dalam hal ini peranan pemerintah baik pada tingkat kelurahan maupun kota Tomohon sangat dibutuhkan untuk terus mengawal kegiatan seperti ini. Para aktivis PATBM yang telah dilatih perlu didukung dengan pendampingan dari Dinas Pemberdayaan Perempuan dan Perlindungan Anak Kota Tomohon, diberikan bantuan media edukasi dan dana operasional yang memadai baik dari pemerintah maupun dunia usaha (CSR) untuk merealisasikan komitmen mereka dalam perlindungan anak.
\end{abstract}

Kata Kunci: Perlindungan Anak Terpadu Berbasis Masyarakat.

\section{PENDAHULUAN}

\section{Analisis Situasi}

Masyarakat di Kelurahan Kinilow I Kota Tomohon merupakan masyarakat yang majemuk meskipun pada awalnya berasal dari satu sub-etnis yaitu Tombulu Minahasa. Namun seiring dengan masuknya berbagai pendatang maka keragaman atau heterogenitas ikut mewarnai perkembangan kehidupan sosial-budayanya.

Kontak dengan pendatang dan masuknya nilai-nilai baru akibat kemajuan teknologi informasi ternyata memiliki dampak yang kompleks baik dampak positif maupun negatif. Meskipun nilai gotong-royong seperti mapalus masih tetap terpelihara namun nilainya telah bergeser menjadi sejenis nilai "arisan" yang dihitung berdasarkan berapa yang "diberikan" itu juga yang "diterima". Kondisi ini pada satu sisi dapat mendorong masyarakat untuk semakin rajin bekerja tetapi pada sisi lainnya telah meningkatkan individualisme dan berangsur-angsur mulai melepaskan 
diri dari kolektivitas komunitas. Oleh sebab itu apabila ada keluarga-keluarga yang tidak siap menerima kondisi ini biasanya mereka menjauhkan diri dari perkumpulan rukun yang ada di lingkungan mereka. Demikian juga afiliasi terhadap golongan agama tertentu tidak jarang menjadi tembok pemisah secara sosial-religius. Mereka terpisah secara sosial tetapi secara fisik masih tinggal dan menetap di lingkungan yang sama.

Nilai-nilai sosial budaya yang mengutamakan pembentukan karakter mulia, secara berangsur-angsur mulai dianggap tidak sesuai dengan perkembangan zaman, penduduk usia anak lebih menggemari Budaya Populer (Popular Culture) yang disuguhkan oleh berbagai media yang tersedia di masyarakat.

Seiring dengan meningkatnya kemajuan teknologi di bidang permainan, maka terdapat berbagai jenis permainan yang sangat memikat dan digemari oleh anakanak. Tanpa disadari berbagai jenis permainan modern ternyata syarat dengan kemerosotan karakter. Perilaku anak lebih dominan dibentuk oleh apa yang mereka gemari. Tokoh-tokoh yang licik, suka menyenangkan diri sendiri, suka menang sendiri, menjadi idola karena kemampuannya yang luar biasa; bahkan spiritisme dengan kekuatan ajaib telah menghipnotis anak-anak untuk menghayalkan diri mereka sebagai pribadi yang tangguh, tidak terkalahkan dengan kekuatan sihir yang tidak tertandingi melalui sinetron atau film yang dapat ditonton secara bebas (termasuk yang dapat diakses dari internet).

Anak-anak yang kepribadiannya telah dibentuk oleh tokoh-tokoh licik, sombong, suka menyenangkan diri akan sangat sukar menjadi pribadi yang jujur, rendah hati, suka menolong, bahkan mau berlaku adil dan bertanggung jawab. Selanjutnya mereka kurang mampu melihat keindahan tabiat yang dipantulkan oleh pendidik yang memiliki disiplin yang tinggi dan selalu tegas dalam bertindak. Sebaliknya sosok pendidik seperti itu akan dianggap sebagai sosok yang buruk dan patut dibenci karena dianggap kaku, ortodoks bahkan dianggap "tidak gaul", suka mengekang dan tidak mengerti selera anak dan remaja masa kini.

Dalam kondisi seperti ini orang tua dan juga guru perlu dibekali dengan keterampilan di bidang perlindungan anak agar mereka mengetahui cara yang tepat dalam pemenuhan hak dan perlindungan anak.

Sesungguhnya tidak ada orang tua yang mau berbuat jahat pada anak-anaknya. Tetapi karena ketidak-tahuan dan pemahaman yang keliru terhadap upaya untuk melindungi anak maka banyak orang tua justru menjadi "perusak anak". Ada banyak fakta tentang hal ini seperti memukul anak yang ditujukan untuk mendidik anak, hal ini kemudian menjadi acuan generasi berikutnya sehingga lingkaran kekerasan tidak akan pernah putus. Ada juga jenis kekeliruan dengan mengikat anak agar 
tidak kemana-mana (supaya terlindungi) seperti yang tampak pada gambar berikut.

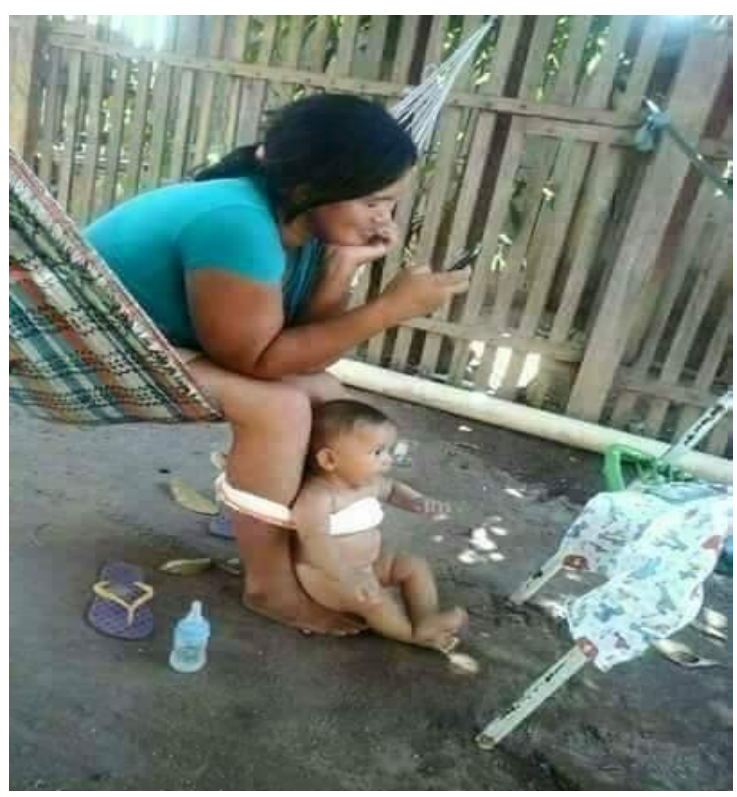

Gambar 1. Gambaran tentang pengasuhan dan perlindungan yang keliru terhadap anak.

Anak sebagai peserta didik, tidak jarang mendapatkan perlakuan salah di sekolah padahal mereka memiliki hak atas perlindungan di sekolah Para guru yang tidak professional dan masih memiliki paradigma mendidik dan mendisiplin secara otoriter tidak jarang telah melakukan tindak kekerasan pada peserta didik di sekolah ketika menangani anak yang suka melawan, tidak disiplin bahkan melakukan tindakan-tindakan menyimpang lainnya (Umbase, R. 2016).

Berdasarkan keseluruhan uraian tentang situasi di Kelurahan Kinilow I maka pelatihan PATBM sebagai gugus pemenuhan hak dan perlindungan anak di Kelurahan Kinilow I penting untuk dilakukan, sekaligus juga ditujukan untuk memperkuat gerakan PATBM yang telah digagas oleh pemerintah dalam rangka mengoptimalkan implementasi kebijakan perlindungan anak di Indonesia.

\section{Permasalahan Mitra}

Berdasarkan permasalahan tersebut maka dapat disimpulkan beberapa sumber permasalahan, yaitu:

1. Kurangnya pengetahuan dan keterampilan orang tua dalam pemenuhan hak dan perlindungan anak;

2. Kurangnya pelatihan khusus tentang pengasuhan, pendidikan dan perlindungan anak terpadu berbasis masyarakat (PATBM);

3. Kurangnya pengetahuan dan keterampilan bahkan rendahnya kesadaran masyarakat untuk bertangung jawab secara bersama-sama dalam memberikan perlindungan terhadap anak; dan

4. Kurangnya pengetahuan dan keterampilan anak untuk menghindari dan menghadapi tindak kekerasan, perlakuan salah, eksploitasi bahkan human trafficking.

\section{Tujuan dan Manfaat}

Kegiatan pengabdian kepada masyarakat yang dilaksanakan di Kelurahan Kinilow I Kota Tomohon, bertujuan untuk:

1. Meningkatkan pengetahuan dan keterampilan masyarakat dalam pemenuhan hak dan perlindungan anak; 
2. Melatih dan merekrut perangkat kelurahan, tokoh agama dan tokoh masyarakat Perlindungan Anak Terpadu Berbasis Masyarakat (PATBM);

3. Meningkatkan keterampilan dan kesadaran masyarakat untuk mengenali berbagai jenis kekerasan, ekspolitasi, penelantaran dan perlakuan salah pada anak sehingga dapat mencegah dan melakukan penanganan apabila ada anak yang menjadi korban; dan

4. Meningkatkan pengetahuan dan keterampilan orang tua dan anak untuk menghindari dan menghadapi tindak kekerasan, perlakuan salah, eksploitasi seksual khususnya human trafficking .

Kegiatan pengabdian kepada masyarakat yang dilaksanakan di Kelurahan Kinilow I Kota Tomohon diharapkan bermanfaat untuk:

1. Mengubah paradigma atau pola pikir bahkan sikap dan perilaku masyarakat dalam pemenuhan hak dan perlindungan anak;

2. Menggugah kesadaran masyarakat untuk terlibat dan berpartisipasi dalam mencegah dan memberikan penanganan bahkan pendampingan pada korban kekerasan, eksploitasi, penelantaran dan perlakuan salah;

3. Memperluas jejaring PATBM secara mandiri dan holistik-sistemik; dan

4. Menjadi masukan bagi pemerintah (kelurahan, kecamatan dan kota) serta OPD/SKPD terkait untuk dapat bersinergi dalam mendukung gerakan PATBM.

\section{METODE PELAKSANAAN}

\section{Kerangka Pemecahan Masalah}

Berdasarkan permasalahan yang dihadapi mitra maka dibutuhkan tindakan solutif untuk mengeliminir permasalahan-permasalahan yang telah diuraikan yaitu:

1. Meningkatkan pengetahuan, keterampilan dan kesadaran tentang perlindungan anak terpadu berbasis masyarakat (PATBM) melalui kegiatan pelatihan PATBM;

2. Mengadakan pelatihan bagi perangkat kelurahan, tokoh agama (semua lintas agama), tokoh masyarakat tentang PATBM;

3. Membentuk kelompok aktivis PATBM secara lebih luas sebagai bentuk gugus tugas pendampingan dalam pemenuhan hak dan perlindungan anak di setiap lingkungan; dan

4. Melakukan kampanye PATBM bersama perangkat kelurahan, tokoh agama, tokoh masyarakat yang telah dilatih.

Metode pelaksanaan kegiatan pengabdian kepada masyarakat Kelurahan Kinilow I Kota Tomohon yaitu Pelatihan yang bersifat partisipatif dalam kegiatan PATBM. Ada empat tahapan pelaksanaan kegiatan: 1) koordinasi dengan pihak terkait; 2) pelaksanaan pelatihan; 3) analisis dan evaluasi; dan 4) pelaporan hasil kegiatan pelatihan/pengabdian kepada masyarakat ke LPPM. 


\section{Pelaksanaan Kegiatan}

Kegiatan pengabdian kepada masyarakat telah dilaksanakan pada masyarakat Kelurahan Kinilow I Kecamatan Tomohon Utara Kota Tomohon pada bulan September - Oktober 2018. Tahapan-tahapan pelaksanaan kegiatan telah dilakukan sesuai dengan rencana kegiatan yang telah diajukan yaitu:

1. Koordinasi kegiatan dengan Kepala Badan Pemberdayaan Perempuan dan Perlindungan Anak serta Keluarga Berencana Kota Tomohon, Lurah Kinilow I. serta Ketua Aktivis PATBM Kelurahan Kinilow I sekaligus merundingkan rencana/jadwal pelaksanaan kegiatan pelatihan PATBM;

2. Pelaksanaan kegiatan tahap pertama yaitu pelatihan dan pemantauan keterlaksanaannya termasuk mengidentifikasi faktor-faktor pendukung dan penghambat dalam Pelatihan PATBM. Pada bulan September minggu ketiga telah dilaksanakan kegiatan Pelatihan PATBM;

3. Analisis dan evaluasi hasil pelaksanaan pelatihan pada bulan Oktober 2018;

4. Pembahasan hasil evaluasi kegiatan pelatihan bersama Ketua dan Aktivis PATBM Kelurahan Kinilow I pada bulan Oktober dan perumusan kesimpulan dan saran untuk ditindak-lanjuti oleh para Aktivis PATBM; dan

5. Pelaporan hasil kegiatan pelatihan/ pengabdian kepada masyarakat ke LPPM pada bulan Nopember 2018.

\section{HASIL DAN PEMBAHASAN}

Kegiatan pengabdian pada masyarakat telah dilakukan oleh Tim Pelaksana yang telah memiliki kualifikasi yang memadai untuk melaksanakan kegiatan tersebut, sekaligus telah melibatkan mahasiswa untuk terlibat secara langsung dalam keseluruhan proses pelaksanaan kegiatan pelatihan.

Universitas Negeri Manado sebagai salah satu perguruan tinggi negeri di Indonesia, memiliki kompetensi di bidang pendidikan, penelitian dan pengabdian kepada masyarakat. Dalam hal pelaksanaan pengabdian untuk melakukan pelatihan PATBM di Kelurahan Kinilow I Tomohon sebagaimana telah dijelaskan pada metode pelaksanaannya, maka perguruan tinggi telah mempersiapkan fasilitator/instruktur untuk kegiatan tersebut. Pelaksana kegiatan pelatihan PATBM ini, merupakan tenaga dosen professional yang memiliki keahlian khusus dalam bidang perlindungan anak (memiliki Sertifikat sebagai Fasilitator PATBM dan Sistem Perlindungan Anak (SPA) sebagai Fasilitator Nasional dari Kementerian Pemberdayaan Perempuan dan Perlindungan Anak Republik Indonesia), menjadi Tenaga Ahli dalam penyusunan Naskah Akademik Ranperda Perlindungan Anak di Sulawesi Utara. Peneliti dan Nara Sumber dalam Pemenuhan Hak dan Perlindungan Anak Indonesia. 


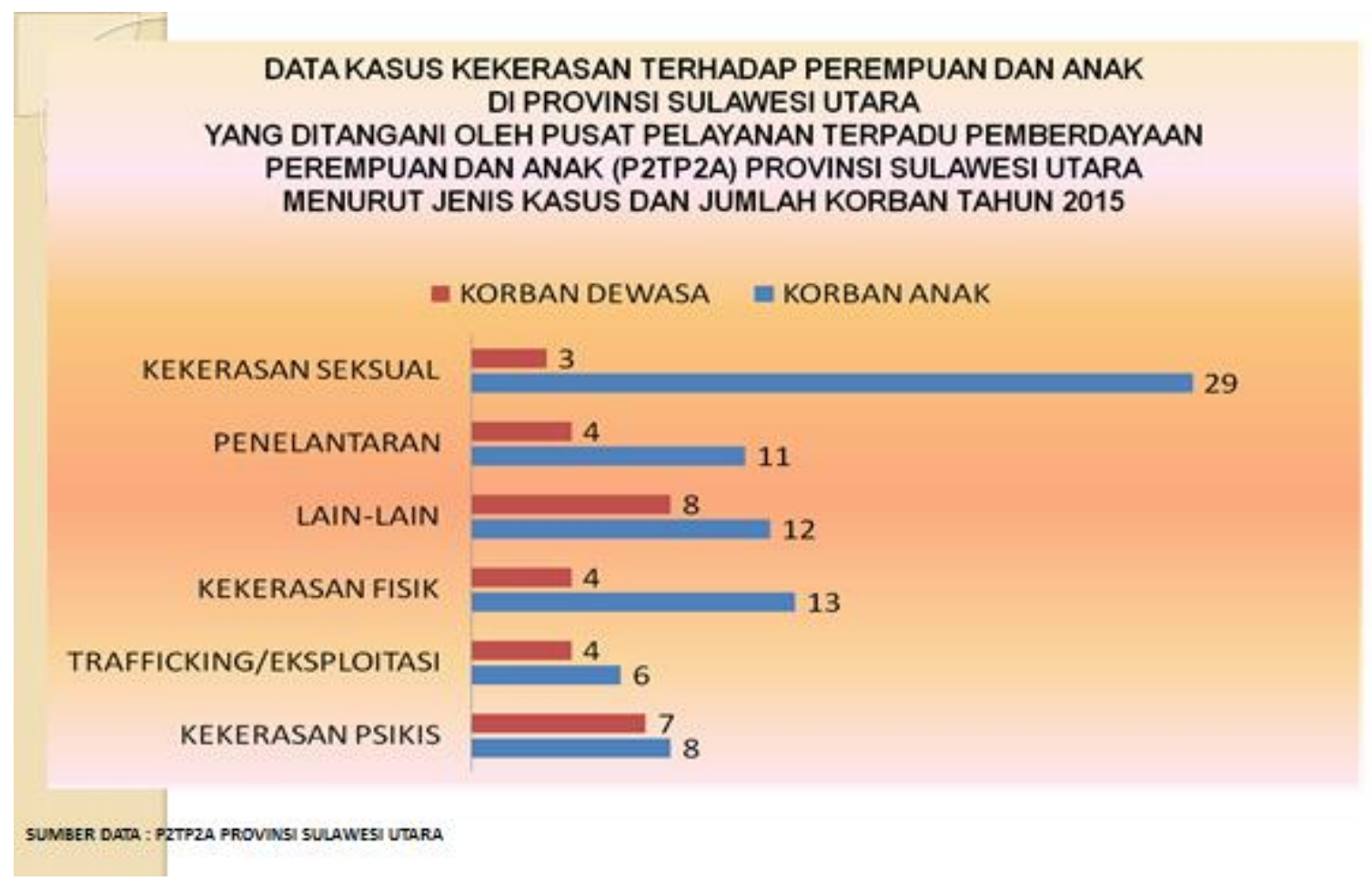

Gambar 2. Data kasus kekerasan terhadap perempuan dan anak di Provinsi Sulawesi Utara.

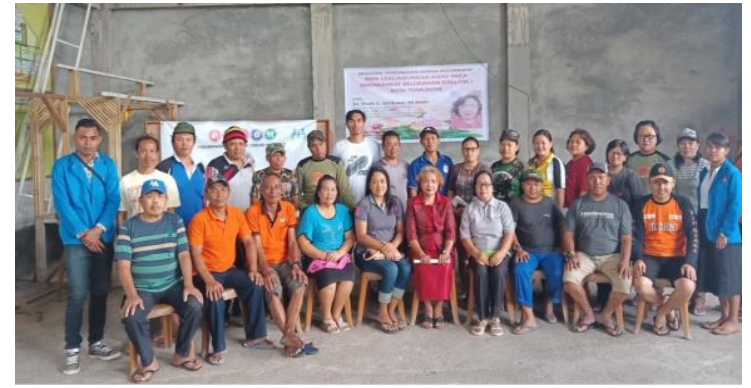

KEGIATAN PENGABDIAN KEPADA MASYARAKAT PKM PERLINDUNGAN ANAK PADA MASYARAKAT KELURAHAN KINILOW I KOTA TOMOHON

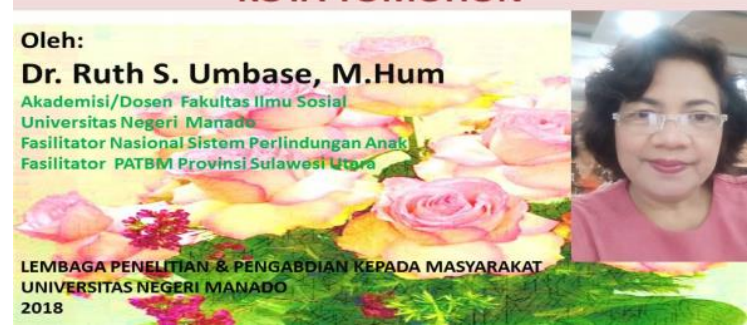

Gambar 3. Dokumentasi pelaksanaan kegiatan.

Hasil pelaksanaan kegiatan pengabdian kepada masyarakat di Kelurahan Kinilow I
Kecamatan Tomohon Utara Kota Tomohon adalah sebagai berikut:

1. Adanya kelompok Aktivis PATBM terlatih dalam hal pemenuhan dan perlindungan anak;

2. Terbentuknya gugus tugas PATBM yang telah dilatih untuk dapat melaksanakan tugas pencegahan tindak kekerasan, eksploitasi, penelantaran dan perlakuan salah terhadap anak;

3. Terbentuknya gugus tugas PATBM yang telah dilatih untuk dapat melaksanakan tugas penanganan dan pendampingan terhadap korban kekerasan, eksploitasi, penelantaran dan perlakuan salah terhadap anak; dan

4. Adanya kelompok Aktivis PATBM yang memiliki komitmen untuk merekrut 
relawan yang secara sukarela dapat memperluas jejaring dan pengaruh positif untuk melindungi anak dari tindak kekerasan, eksploitasi, penelantaran dan perlakuan salah.

\section{KESIMPULAN DAN SARAN}

\section{Kesimpulan}

Berdasarkan keseluruhan proses dan hasil pelaksanaan kegiatan pengabdian kepada masyarakat di Kelurahan Kinilow I Kecamatan Tomohon Utara Kota Tomohon Provinsi Sulawesi Utara tentang Perlindungan Anak Terpadu Berbasis Masyarakat (PATBM) dapat disimpulkan hal-hal sebagai:

1. Dalam proses pelaksanaan kegiatan pengabdian kepada masyarakat maka koordinasi dan sinergisitas pelaksanaan kegiatan di antara semua pihak terkait merupakan aspek penentu awal keberhasilan pelaksanaan kegiatan;

2. PKM Perlindungan Anak Terpadu Berbasis Masyarakat (PATBM) pada Masyarakat di Kelurahan Kinilow I Kecamatan Tomohon Utara Kota Tomohon telah dilaksanakan melalui Model Partisipatif yang diterapkan dalam bentuk Metode Pelatihan dan Aplikasi Model PATBM yang partisipatif; dan

3. Hasil kegiatan yang dicapai yaitu adanya kelompok Aktivis PATBM yang terlatih dalam pemenuhan dan perlindungan anak; pencegahan tindak kekerasan, eksploitasi, penelantaran dan perlakuan salah terhadap anak; telah dilatih untuk dapat melaksanakan tugas penanganan awal dan pendampingan terhadap korban kekerasan, eksploitasi, penelantaran dan perlakuan salah terhadap anak; serta adanya komitmen untuk dapat melaksanakannya secara sungguh-sungguh dan berkelanjutan.

\section{Saran}

Berdasarkan kesimpulan hasil pelaksanaan kegiatan pengabdian kepada masyarakat tersebut dapat disarankan hal-hal sebagai berikut:

1. Dibutuhkan persiapan yang matang dalam perencanaan, pelaksanaan dan evaluasi kegiatan. Adanya koordinasi dan sinergisitas dalam pelaksanaan kegiatan dengan semua pihak terkait yang memiliki tugas dan tanggungjawab untuk keberhasilan pelaksanaan kegiatan;

2. Dibutuhkan dukungan pihak pemerintah dan dunia usaha (CSR) untuk memaksimalkan hasil yang telah dicapai melalui kegiatan pelatihan. Hal ini dapat dilakukan dengan cara menindak-lanjuti dengan berbagai program/kegiatan yang relevan; dan

3. Para Aktivis PATBM yang telah dilatih perlu di dukung dengan media dan bantuan dana operasional yang memadai sehingga dapat merealisasikan komitmennya secara maksimal. 


\section{KEPUSTAKAAN}

KPP-PA RI, Modul Perlindungan Anak Terpadu Berbasis Masyarakat, (Jakarta: Deputi Perlindungan Anak), 2016.

Undang-Undang RI Nomor 23 tahun 2002 tentang Perlindungan Anak.

Undang-Undang RI Nomor 35 tahun 2014 tentang Perubahan terhadap UndangUndang RI Nomor 23 tahun 2002 tentang Perlindungan Anak.
Undang-Undang RI Nomor 16 tahun 2016 tentang Perubahan Kedua terhadap Undang-Undang RI Nomor 23 tahun 2002 tentang Perlindungan Anak.

Umbase, Ruth. Paradigma Pendidikan Demokratis dan Hak Anak Atas Perlindungan Di Sekolah. (JakartaPalembang: ASWGI, KPP-PA dan Universitas Sriwijaya), 2016. 